Миргород-Карпова Валерія Валеріївна кандидат юридичних наук, заступник директора 3 наукової роботи, старший викладач кафедри адміністративного, господарського права та фінансово-економічної безпеки, Навчально-науковий інститут права Сумського державного університету, вул. Петропавлівська, 59, м. Суми, 40000, тел.: (099) 473-51-43, e-mail: vv_myrhorod@ukr.net, https://orcid.org/0000-0002-3302-221X

Старинський Микола Володимирович доктор юридичних наук, доцент, професор кафедри адміністративного, господарського права та фінансовоекономічної безпеки, Навчально-науковий інститут права Сумського державного університету, вул. Петропавлівська, 59, м. Суми, 40000, тел.: (099) 901-98-01, e-mail: starinskiy_nik@ukr.net, https://orcid.org/0000-0003-2661-5639

Шлапко Тетяна Вікторівна кандидат юридичних наук, доцент кафедри адміністративного, господарського права та фінансово-економічної безпеки, Навчально-науковий інститут права Сумського державного університету, вул. Петропавлівська, 59, м. Суми, 40000, тел.: (099)38-57-11, e-mail: tanlike@ukr.net, https://orcid.org/0000-0003-1619-3831

\title{
МІЖНАРОДНО-ПРАВОВІ АКТИ ЩОДО ЗАБЕЗПЕЧЕННЯ ПРАВ СПОЖИВАЧІВ МЕДИЧНИХ ПОСЛУГ ${ }^{1}$
}

Анотація. Право на здоров'я $\epsilon$ основоположним правом людини i громадянина, а в юридичному аспекті виступає як особисте немайнове невід'ємне право кожного та виступає в ролі великої соціальної цінності. Тісно пов'язане 3 даним правом $\epsilon$ право на медичні послуги, належні медичну допомогу та ефективне надання медичних послуг загалом. Реалізація в Україні права на охорону здоров'я відбувається на низькому рівні, про що говорять світові офіційні дані. Дані обставини вимагають пошуку нових шляхів виходу із кризи у сфері надання медичних послуг та захисту прав і законних інтересів особи і громадянина в Україні. Імплементація світових стандартів в даній сфері є одним із ключових шляхів ефективного розвитку сфери і забезпечення права на здоров'я. Враховуючи це в рамках даної статті нами були досліджені ключові

1 Робота виконана в рамках договору № БФ/24-2021 щодо «Виконання завдань перспективного плану розвитку наукового напряму «Суспільні науки» Сумського державного університету» (Економіко-математичне моделювання та прогнозування, створення методологічного та методичного підгрунтя побудови дорожньої карти реформ системи охорони здоров'я в Україні з урахуванням конвергентної взаємодії поведінкових, соціальних, економічних та правових детермінант) 
міжнародні нормативно-правові акти, зокрема Загальна декларація прав людини, Хельсінська декларація, Конвенція про захист прав і гідності людини в зв'язку з використанням досягнень біології i медицини, Лісабонська декларація, Декларація про розвиток прав пацієнтів в Європі, Європейська хартія пацієнтів, Міжнародний пакт про економічні, соціальні і культурні права тощо. Окреслюючи основні міжнародні та європейські стандарти забезпечення прав споживачів медичних послуг, в статті зроблено акцент на діючу нормативноправову базу з даного питання, визначені ії особливості, недоліки, прогалини та перспективи розвитку. Досліджено питання щодо перспективи створення єдиного кодифікованого нормативно-правового акту у сфері надання медичних послуг 3 урахування світових надбань та міжнародних стандартів забезпечення прав споживачів медичних послуг.

Ключові слова: споживачі медичних послуг, пацієнти, лікарі, міжнародні та європейські стандарти, міжнародні нормативно-правові акти у сфері надання медичних послуг.

Myrhorod-Karpova Valeria Valeriyivna Candidate of Law, Deputy Director for Research, Senior Lecturer of the Department of Administrative, Economic Law and Financial and Economic Security of the Educational and Scientific Institute of Law Sumy State University, Petropavlivska St., 59, Sumy, 40000, tel.: (099) 473-51-43, email: vv_myrhorod@ukr.net, https://orcid.org/0000-0002-3302-221X

Starynsky Mykola Volodymyrovych Doctor of Law, Associate Professor, Professor of the Department of Administrative, Economic Law and Financial and Economic Security of the Educational and Scientific Institute of Law of Sumy State University, Petropavlivska St., 59, Sumy, 40000, tel.: (099) 901-98-01, e-mail: starinskiy_nik@ukr.net, https://orcid.org/0000-0003-2661-5639

Shlapko Tetyana Viktorivna Candidate of Law, Associate Professor of the Department of Administrative, Economic Law and Financial and Economic Security of the Educational and Scientific Institute of Law of Sumy State University, Petropavlivska St., 59, Sumy, 40000, tel .: (099) 38-57-11, e-mail: tanlike@ukr.net, https://orcid.org/0000-0003-1619-3831

\section{INTERNATIONAL LEGAL ACTS ON ENSURING THE RIGHTS OF CONSUMERS OF MEDICAL SERVICES}

Abstract. The right to health is a fundamental right of a person and a citizen, and in the legal aspect it acts as a personal inalienable inalienable right of everyone and acts as a great social value. Closely related to this right is the right to medical services, adequate medical care and the effective provision of medical services in general. The implementation of the right to health care in Ukraine is at a low level, according to 
world official data. These circumstances require the search for new ways out of the crisis in the field of medical services and protection of the rights and legitimate interests of individuals and citizens in Ukraine. The implementation of world standards in this area is one of the key ways to effectively develop the field and ensure the right to health. With this in mind, in this article we have examined key international regulations, including the Universal Declaration of Human Rights, the Declaration of Helsinki, the Convention for the Protection of Human Rights and Dignity in Respect of the Use of Biology and Medicine, the Lisbon Declaration, and the Declaration on the Development of Human Rights. patients in Europe, the European Charter of Patients, the International Covenant on Economic, Social and Cultural Rights, etc. Outlining the main international and European standards of ensuring the rights of consumers of medical services, the article focuses on the current regulatory framework on this issue, identifies its features, shortcomings, gaps and prospects for development. The issue of the prospect of creating a single codified legal act in the field of medical services, taking into account world heritage and international standards for ensuring the rights of consumers of medical services.

Keywords: consumers of medical services, patients, doctors, international and European standards, international regulations in the field of medical services.

Постановка проблеми. Питання адаптації вітчизняного законодавства до міжнародних стандартів $\epsilon$ одним із ключових питань сьогодення. Однак, враховуючи реалізацію заходів медичної реформи в Україні, сфера надання медичних послуг 3 кожним роком набирає все більшої актуальності. Адже із впровадженням реформаційних заходів, реальна картина в медичній сфері не змінюється в бік збільшення ефективності та результативності. Враховуючи відсутність в Україні дієвого механізму усунення існуючих роками проблем, вважаємо, що саме імплементація міжнародних і європейських стандартів може стати поштовхом до дійсного реформування сфери.

Аналіз останніх досліджень і публікацій. В Україні відсутні комплексні дослідження впровадження в сфері медичних послуг міжнародних і європейських стандартів $з$ грунтовним аналізом нормативно-правового базису. Разом 3 тим, в тій чи іншій мірі дана сфера буда досліджена такими науковцями як А. М. Савицька, С. Б. Булеца, О. О. Прасова, С. В. Михайлов тощо.

Метою статті є дослідження ключових міжнародних нормативно-правових актів, що закріплюють базові міжнародні та європейські стандарти захисту прав споживачів медичних послуг та можливості їх імплементації в Україні 3 урахування сучасних реалій розвитку сфери та реалізації медичної реформи.

Виклад основного матеріалу. Адаптація вітчизняного законодавства до базових принципів функціонування законодавства ЄС є одним із основних питань сьогодення та одним із ключових векторів у співпраці України та ЄС. Ще в 1998 році після ухвалення Угоди про партнерство та співпрацю між $\mathrm{CC}$, їх державамичленами та Україною офіційно задекларовано «бажання Сторін встановити тісні 
стосунки, побудовані на існуючих історичних зв'язках». Фактична адаптація розпочалася в 2004 році із ухваленням та прийняття чинності Закону України «Про загальнодержавну програму адаптації Законодавства України до законодавства Свропейського Союзу». Саме Загальною програмою адаптації законодавства України до законодавства СС визначено механізм досягнення Україною відповідності третьому Копенгагенському та Мадридському критеріям набуття членства в Європейському Союзі. Цей механізм включає адаптацію законодавства, утворення відповідних інституцій та інші додаткові заходи, необхідні для ефективного правотворення та правозастосування. Метою адаптації законодавства України до законодавства Європейського Союзу $є$ досягнення відповідності правової системи України acquis communautaire 3 урахуванням критеріїв, що висуваються Європейським Союзом (ЄС) до держав, які мають намір вступити до нього. Адаптація законодавства України до законодавства ЄС $є$ пріоритетною складовою процесу інтеграції України до Свропейського Союзу, що в свою чергу є пріоритетним напрямом української зовнішньої політики [1].

Досліджуючи ключові аспекти адаптації законодавства України до законодавства ЄС О. Ю. Бойко визначає, що одним із найбільш актуальних питань даної сфери є запровадження в Україні європейських стандартів забезпечення прав пацієнтів як споживачів медичних послуг. Так, у своїй роботі «Міжнародно-правові концепція охорони прав пацієнтів» дослідник вказує на історичний аспект даного питання та зауважує, що міжнародна охорона прав споживачів медичних послуг набула найбільшої актуальності в середині минулого століття, що тісно пов'язано з необхідністю створення ефективного та діючого механізму захисту прав і свобод людини і громадянина у всіх сферах суспільного життя. Саме Загальною декларацією прав людини, котра була прийнята в 1948 році акцентовано особливу увагу на необхідності належного медичного захисту і догляду та діюче соціальне забезпечення і обслуговування. Дані елементи визначені як складові належного забезпечення прав і законних свобод осіб, що дозволяє сформувати достатній життєвий рівень [2, с. 163].

Зауважимо, що всі сучасні вектори розвитку сфери забезпечення прав i інтересів пацієнтів як споживачів медичних послуг закладені в різні історичні етапи декларування. При цьому, як зауважує А. А. Герц у своєму дисертаційному дослідженні «Договірні зобов'язання у сфері надання медичних послуг» стверджує, що ключовою передумовою зародження правового декларування виступила необхідність чіткого регламентування роботи лікаря та визначення його адміністративно-правового статусу. 3 часом поступово врегульовувалися окремі аспекти сфери захисту прав пацієнтів як споживачів медичних послуг [3]. Наприклад, в Хельсінській декларації в 1964 році в статті 9 вперше акцентовано увагу на порядок проведення експерименту. Задекларовано, що для проведення будь-якого експерименту лікар зобов'язаний отримати від учасника експерименту добровільну інформовану згоду, бажано у письмовій формі. Учасники будь-якого експерименту повинні бути повідомлені про те, що вони 
мають право відмовитися від участі в експерименті взагалі, а також можуть припинити свою участь у будь-який момент. А вже в 1994 році Декларацією про політику в сфері забезпечення прав пацієнтів в Свропі задекларовано, що інформована добровільна згода пацієнта $\epsilon$ попередньою умовою будь-якого медичного втручання. Пацієнт має право відмовитися від медичного втручання чи призупинити його проведення.

Конвенцією про захист прав і гідності людини в зв'язку з використанням досягнень біології і медицини 1997 року визначено, що будь-яке втручання у сферу здоров'я може здійснюватися тільки після добровільної та свідомої згоди на нього відповідної особи. Такій особі заздалегідь надається відповідна інформація про мету і характер втручання, а також про його наслідки та ризики. Відповідна особа у будь-який час може безперешкодно відкликати свою згоду.

В межах даного дослідження нами систематизовано основні міжнародні та європейські документи щодо захисту прав споживачів медичнх послуг, котрі ратифіковані в Україні та створюють прямий вплив на формування законодавчого базису функціонування даної сфери (Таблиця 1).

Таблиия 1.

Основні міжнародні та свропейські документи щодо захисту прав споживачів медичних послуг ратифіковані в Україні

\begin{tabular}{|c|c|c|c|}
\hline /II & Назва документу & Дата підписання & Дата ратифікації \\
\hline 1. & $\begin{array}{l}\text { Міжнародний пакт про громадянські і } \\
\text { політичні права від 16.12.1966 }\end{array}$ & 20.03 .1968 & 19.10 .1973 \\
\hline 2. & $\begin{array}{l}\text { Факультативний } \quad \text { протокол } \\
\text { Міжнародного пакту про громадянські } \\
\text { та політичні права від 16.12.1966 }\end{array}$ & $\begin{array}{c}25.12 .1990 \\
\text { (приєднання) }\end{array}$ & $\begin{array}{c}25.10 .1991 \\
\text { (набуття чинності) }\end{array}$ \\
\hline 3. & \begin{tabular}{llll} 
Міжнародний пакт про & \multicolumn{2}{l}{ економічні, } \\
соціальні i & культурні & права ві \\
16.12 .1966 & & & \\
\end{tabular} & 19.10 .1973 & 19.10 .1973 \\
\hline 4. & $\begin{array}{l}\text { Конвенція про ліквідацію всіх } \\
\begin{array}{l}\text { дискримінації } \\
\text { щодо жіно } \\
\text { 18.12.1979 }\end{array} \\
\end{array}$ & 19.12.1980 & $\begin{array}{c}03.09 .1981 \\
\text { (набуття чинності) }\end{array}$ \\
\hline 5. & $\begin{array}{l}\text { Міжнародна конвенція про ліквідацію } \\
\text { всіх форм расової дискримінації від } \\
21.12 .1965\end{array}$ & 07.03 .1966 & 21.01.1969 \\
\hline 6. & $\begin{array}{l}\text { Конвенція проти катувань та інших } \\
\text { жорстоких, нелюдських або таких, що } \\
\text { принижують гідність, } \\
\text { поводження і покарання від } 10.12 .1984\end{array}$ & 10.12 .1984 & 26.01 .1987 \\
\hline 7. & 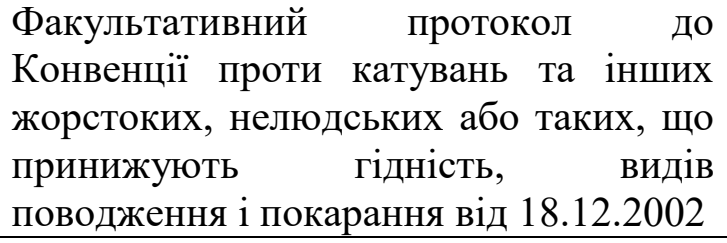 & 18.12 .2002 & $\begin{array}{l}21.07 .2006 \\
\text { (ратифікація) }\end{array}$ \\
\hline
\end{tabular}




\begin{tabular}{|l|l|c|c|}
\hline 8. & $\begin{array}{l}\text { Конвенція про права дитини від } \\
20.11 .1989\end{array}$ & 20.11 .1989 & 27.09 .1991 \\
\hline 9. & $\begin{array}{l}\text { Міжнародна конвенція про захист прав } \\
\text { усіх трудящих мігрантів і членів ї } \\
\text { сімей від 18.12.1990 }\end{array}$ & Нетифікована \\
\hline 10. & $\begin{array}{l}\text { Конвенція про права інвалідів від } \\
13.12 .2006\end{array}$ & 13.12 .2006 & Не ратифікована \\
\hline 11. & $\begin{array}{l}\text { Конвенція про захист прав і гідності } \\
\text { людини щодо застосування біології та } \\
\text { медицини: Конвенція про права } \\
\text { людини та біомедицину від 04.04.1997 }\end{array}$ & 22.03 .2002 & 11.09 .1997 \\
\hline 12. & $\begin{array}{l}\text { Конвенція про захист прав людини і } \\
\text { основоположних свобод (Свропейська } \\
\text { конвенція про права людини) від } \\
\text { О4.11.1950 }\end{array}$ & 04.11 .1950 & Не ратифікована \\
\hline 13. & $\begin{array}{l}\text { Європейська соціальна хартія від } \\
18.10 .1961 ~\end{array}$
\end{tabular}

Джерело: створено авторами на підставі наукових доробок I. Сенюти [4].

Поступово в медичні сфері все більшої актуальності зазнавав вектор офіційного визнання та декларування основоположних прав та принципів в даній сфері. Так, Лісабонською деклараціє 1981 року закріплено ключові права в медичній сфері. В статті 3 декларації зазначено, що пацієнт як споживач медичних послуг має право приймати незалежні рішення щодо свого здоров'я (право пацієнта на самовизначення), лікар зобов'язаний пояснити пацієнту про наслідки прийнятого рішення. Повнолітній дієздатний пацієнт має право погоджуватися на будь-яку діагностичну процедуру чи терапію, а також відмовлятися від них.

Разом 3 тим, одними із найбільш вагомих міжнародних документів, котрі були розроблені і прийняті на території Європи та зробили найбільш вагомий вклад у загальний розвиток європейського законодавства щодо врегулювання сфери надання медичних послуг та захисту прав і законних інтересів пацієнтів $\epsilon$ Амстердамська декларація або Декларація про розвиток прав пацієнтів в Європі 1994 року та Європейська хартія пацієнтів 2002 року. Дослідники зауважують, що саме Декларація про розвиток прав пацієнтів в Свропі визначила стратегію просування прав пацієнтів в Свропі разом із наданням ефективних практичних рекомендацій, окреслила базові принципи щодо прав пацієнтів. Базові права, котрі були задекларовані даним документом: право на інформацію про медичну допомогу і про те, як їй краще користуватися; право висловлювати згоду в 
процесі отримання медичної допомоги; право на конфіденційність і приватність (недоторканність особистого життя); право на можливість отримання медичної допомоги, відповідно стану здоров'я пацієнта, включаючи профілактичну i лікувальну допомогу [5].

У зв'язку із невиконанням цілого ряду зобов'язань з боку країн ЄС, що прямо вплинуло на погіршення рівня дотримання прав i законних інтересів споживачів медичних послуг, а також якісно позитивного впливу рекомендацій Ради Свропи щодо необхідності та першочерговості участі організацій громадянського суспільства у прийнятті рішень в медичній сфері та реального збільшення активності пацієнтів та їх організацій щодо необхідності врегулювання даної сфери було прийнято рішення щодо ухвалення нового міжнародного документу, котрий вирішив би виникаючі проблеми. Таким документом стала Європейська хартія прав пацієнтів ухвалена в 2002 році. Над детальною доробкою тексту даної декларації взяли участь представники 3 багатьох європейських країн, зокрема Німеччини, Ірландії, Австрії, Італії, Бельгії, Великої Британії, Іспанії, Данії, Греції тощо. В Свропейській хартії конкретизовано та закріплено 14 базових прав пацієнтів: право на профілактичні заходи; право доступу; право на інформацію; право на згоду; право вільного вибору; право на недоторканність приватного життя (приватність) i конфіденційність інформації; право на повагу часу пацієнта; право на дотримання стандартів якості; право на безпеку; право на доступ до сучасних досягнень; право на уникнення невиправданих страждань і болю; право на індивідуалізоване лікування; право подавати скаргу; право на компенсацію.

Завдяки Європейській Хартії з прав пацієнтів, яка визначила нові орієнтири для систем охорони здоров'я країн СС і ввела нові стандарти 3 прав пацієнтів, декілька великих організацій громадянського суспільства 3 СС розробили на основі цих нових стандартів нові індикатори для оцінки роботи системи охорони здоров'я і успішно застосували їх в методології громадянського аудиту в країнах ЄС. Причому, на рівні ЄС ця робота проводилася неодноразово, починаючи 3 2005 p., а їі матеріали були опубліковані і оприлюднені у вигляді доповідей, які були представлені на розгляд Свропейського парламенту в 2005 і 2007 p [5].

Основним документом, де проголошено базові принципи надання медичних послуг є Декларація про медичну допомогу, орієнтовану на пацієнта. У даному документі акцентовано увагу на наступних принципах:

1) принцип поваги, який фіксує, що пацієнти й особи, які надають їм медичну допомогу, користуються фундаментальним правом на охорону здоров’я, яке орієнтоване на пацієнтів і $є$ таким, що гарантує їхні унікальні потреби, переваги та цінності, а також їхню самостійність і незалежність;

2) принцип вибору i розширення можливостей: пацієнти мають право й обов'язок, у міру своїх здібностей і переваг, брати участь як партнери в ухваленні рішень, що стосуються сфери охорони здоров'я, й таких, що впливають на їнє життя. Для цього необхідна система медичного обслуговування, яка реагує на 
потреби пацієнтів і забезпечує адекватний вибір варіантів лікування захворювань, що відповідає цим потребам, а також заохочення й підтримка пацієнтів та осіб, що надають допомогу пацієнтам, задля досягнення якомога вищої якості життя. Організації пацієнтів повинні мати можливість відігравати провідну роль у підтримці пацієнтів та їхніх сімей задля здійснення їхнього права на інформований вибір медичного втручання;

3) принцип участь пацієнтів у формуванні політики у сфері охорони здоров'я, котрий декларує те, що пацієнти й організації пацієнтів повинні мати можливість взяти на себе частину відповідальності за формування політики в сфері охорони здоров'я через реальну та заохочувану участь на всіх рівнях і на всіх етапах ухвалення рішень, щоб у таких рішеннях на чільне місце було поставлено інтереси пацієнта. Вони не повинні обмежуватися політикою у сфері охорони здоров'я, а мають включати в себе, наприклад, соціальну політику, яка в підсумку матиме вплив на життя пацієнтів;

4) принцип доступність і підтримки: пацієнтам повинна бути доступною необхідна медична допомога, під якою розуміються безпечні, якісні й адекватні послуги, види лікування, профілактики та медичної просвіти. Необхідно забезпечити всім пацієнтам доступність послуг незалежно від їхнього стану й соціально-економічного статусу. Щоб пацієнт міг досягнути максимально доступної якості життя, медичне обслуговування повинно задовольняти емоційні вимоги пацієнтів і враховувати немедичні такі фактори, як освіта, зайнятість i сімейні проблеми, які впливають на вибір пацієнтом медичних послуг і на організацію таких послуг;

5) принцип інформування: достовірна, своєчасна й повна інформація необхідна для того, щоб пацієнти та особи, які надають медичну допомогу, могли ухвалювати інформовані рішення про лікування й про те, як жити 3 цим захворюванням. Інформацію необхідно надавати в доступній формі відповідно до принципів медичної деонтології та 3 урахуванням стану здоров'я, мови, віку, інтелекту, здібностей і культури пацієнта [6].

Таблиия 2.

Рівні закріплення прав споживачів медичних послуг на охорону здоров'я

\begin{tabular}{|c|c|c|}
\hline $\begin{array}{l}\text { № } \\
\text { II/II }\end{array}$ & Назва рівня закріплення & $\begin{array}{l}\text { Приклади актів, що відповідають рівням } \\
\text { закріплення }\end{array}$ \\
\hline . & $\begin{array}{l}\text { Універсальний рівень } \\
\text { (акти, що мають декларативний } \\
\text { характер } \quad \text { м } \\
\text { рекомендаційний характер для } \\
\text { суспільства і світу) }\end{array}$ & $\begin{array}{l}\text { Загальна декларація прав людини } 1948 \text { р. } \\
\text { Міжнародний пакт про економічні, соціальні і } \\
\text { культурні права від } 1966 \text { p. } \\
\text { Конвенція про права дитини } 1989 \text { p. } \\
\text { Конвенція про права інвалідів } 2006 \text { p. } \\
\text { Конвенція про ліквідацію всіх форм } \\
\text { дискримінації щодо жінок } 1979 \text { p. } \\
\text { Конвенція про захист прав людини і }\end{array}$ \\
\hline
\end{tabular}


Журнал «Наукові інновації та передові технології»

(Серія «Державне управління», Серія «Право»,

Серія «Економіка», Серія «Психологія», Серія «Педагогіка»)

\begin{tabular}{|c|c|}
\hline & $\begin{array}{l}\text { основоположних свобод } 1950 \text { p. } \\
\text { Міжнародна Конвенція про ліквідацію всіх } \\
\text { форм расової дискримінації } 1965 \text { р. } \\
\text { Конвенція проти катування та інших жорстоких, } \\
\text { нелюдських або таких, що принижують гідність, } \\
\text { видів поводження і покарання } 1984 \text { р. }\end{array}$ \\
\hline $\begin{array}{l}\text { Комплексний рівень } \\
\text { (акти, що регулюють різні права } \\
\text { людини, в тому числі і права в } \\
\text { сфері охорони здоров’я) }\end{array}$ & $\begin{array}{l}\text { Європейська конвенція про соціальну та } \\
\text { медичну допомогу та Протокол до неї } 1953 \text { р. } \\
\text { Свропейська соціальна хартія } 1996 \text { р. } \\
\text { Конвенція про захист прав і гідності людини } \\
\text { щодо застосування біології та медицини } 1997 \text { р. }\end{array}$ \\
\hline $\begin{array}{l}\text { Спеціалізований рівень } \\
\text { (акт, видані спеціалізованими } \\
\text { організаціями) }\end{array}$ & 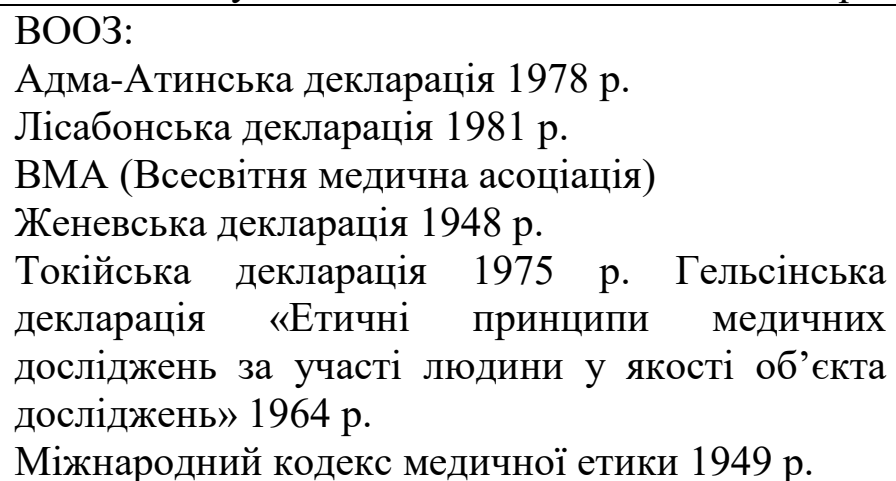 \\
\hline
\end{tabular}

Джерело: складено авторами на підставі досліджень.

Рівень забезпечення і реалізації базових прав і законних інтересів пацієнтів в України перебуває на незадовільному рівні. Окрім абсолютного ігнорування необхідності дотримання прав пацієнтів і відсутності правової культури представників медичного закладу (медичного персоналу),однією із основних причин даної обставини $є$ те, що вітчизняна нормативно-права база у даній сфері $\epsilon$ недостатньою та представлена наступники законодавчими актами, котрі не можуть в повній мірі врегулювати сферу забезпечення прав споживачів медичних послуг. Такими законодавчими актами є:

1) Основний Закон України - Конституція України, де в статті 28 задекларовано, що жодна людина без ії вільної згоди не може бути піддана медичним дослідам; в статті 29 задекларовано, кожна особа має право на свободу та особисту недоторканність;

2) кодифіковані акти - Цивільний кодекс України, де в частині 3 статті 284 визначено, що надання медичної допомоги фізичній особі, яка досягла 14 років, провадиться за іiі згодою; частина 4 статті 284 - повнолітня дієздатна фізична особа, яка усвідомлює значення своїх дій і може керувати ними, має право відмовитися від лікування. В Кримінальному кодексі України передбачено можливість притягнення особи до відповідальності (кримінальної) за окремі види злочинів у сфері охорони здоров'я (ненадання хворому допомоги, незаконна лікувальна діяльність, незаконне розголошення лікарської таємниці тощо). В Кодексі України про адміністративні правопорушення передбачається 
можливість притягнення до відповідальності за такі правопорушення як ухилення від обстеження і профілактичного лікування осіб, хворих на венеричну хворобу, ухилення від медичного обстеження чи огляду. Питання щодо порядку притягнення до відповідальності, а також порядку звернення до судових органів за захистом прав та їх поновленням врегульовані процесуальним законодавством, зокрема Кримінальним процесуальним кодексом України, Цивільним процесуальним кодексом України, Кодексом адміністративного судочинства України.

3) спеціальні закони - Закон України «Основи законодавства України про охорону здоров'я», де в статтях 42 та 43 визначено, що згода інформованого пацієнта необхідна для застосування засобів діагностики, профілактики та лікування. Щодо пацієнта віком до 14 років (малолітнього пацієнта), а також пацієнта, визнаного в установленому законом порядку недієздатним, медичне втручання здійснюється за згодою їх законних представників. Пацієнт, який набув повної цивільної дієздатності і усвідомлює значення своїх дій та може керувати ними, має право відмовитися від лікування. Іншими спеціальним законодавчими актами, котрі врегульовують конкретні питання в сфері надання медичних послуг та захисту прав пацієнтів є Закон України «Про донорство крові та іiі компонентів» від 23.06.1995 р., Закон України «Про страхування» від 07.03.1996 року, Закон України «Про трансплантацію органів та інших анатомічних матеріалів людині» від 16.07.1999 р., Закон України «Про психіатричну допомогу» від 22.02.2000 р., Закон України «Про протидію захворюванню на туберкульоз» від 05.07.2001 p.

4) підзаконні нормативно-правові акти - указ Президента України «Про клятву лікаря» № 349 від 15.06 .1992 р., розпорядження Кабінету міністрів України «Про схвалення Концепції розвитку охорони здоров'я населення України» № 1313/2000 від 07.12.2000 р., розпорядження Кабінету міністрів України «Про схвалення концепції Загальнодержавної програми Здоров’я 2020: український вимір « № 1164-р від 31.10.2013 р.», наказ Міністерства охорони здоров’я України «Про окремі питання організації виконання державних цільових програм і комплексних заходів з охорони здоров’я» № 502 від 10.08.2015 p [6].

Висновки. Враховуючи все вище викладене зауважимо, що вітчизняний законодавчий рівень правового регулювання забезпечення і реалізації прав споживачів медичних послуг в Україні перебуває на незадовільному рівні та характеризується відсутністю систематизації. Наявність значної кількості підзаконних нормативних актів ставить питання щодо наявності значної кількості запозичень та колізій. В медичному праві все частіше підіймається питання щодо необхідності прийняття єдиного нормативно-правового акту кодифікованого характеру, котрий дозволить уникнути вище вказані законодавчі та практичні проблеми. Л. В. Красицька, Р. О. Стефанчук, А. А. Герц висловлюють 
припущення щодо можливості ухвалення Медичного кодексу або Кодексу законів про охорону здоров’я громадян в Україні або Кодекс біомедицини тощо [4]. На нашу думку, така перспектива є досить логічною та перспективною, адже відбудеться чітке розкриття змісту базових прав пацієнтів в Україні, буде сформовано один базовий нормативно-правовий акт, котрий максимально повно врегулює суспільні відносини у сфері споживання медичних послуг, будуть визначені єдині принципи функціонування даної сфери, актуалізується питання щодо формування договірних взаємовідносин в медичні сфері та чіткого закріплення адміністративно-правового статусу лікарів та пацієнтів із єдино встановленим механізмом притягнення до відповідальності. Всі ці обставини потребують застосування ефективного і дієвого зарубіжного досвіду, котрий базується на міжнародних принципах та європейських стандартах.

\section{Лimepamypa:}

1. Про загальнодержавну програму адаптації Законодавства України до законодавства Європейського Союзу: Закон України від 18 березня 2004 року № 1629 https://zakon.rada.gov.ua/laws/show/1629-15\#Text

2. Бойко Ю. Ю. Міжнародно-правова концепція охорони прав пацієнта. Правова позиція. 2018. № 2 (21). C. 162-167.

3. Герц А.А. Договірні зобов'язання у сфері надання медичних послуг. Дис. На здобуття наук. ступ. Докт. Юрид. наук. за спеціальністю 12.00.03. Львів, 2016. 421 с.

4. Права людини у сфері охорони здоровя: практичний посібник / За наук. ред. І. Сенюти. Львів: Вид-во ЛОБФ «Медицина і право», 2012. 552 с.

5. Україна крізь призму Європейської хартії прав пацієнтів: результати виконання в Україні другого етапу європейських досліджень на відповідність стандартам ЄС 3 прав пацієнтів. К. Видавництво ТОВ «Дизайн і поліграфія», 2012. 158 стор.

6. Практичне право: права пацієнтів (Інтерактивний курс медичного права) : навч. посіб. / Галай В. О., Гречанюк С. К., Сенюта І. Я. та ін.; за ред. С. Г. Стеценка та А. О. Галая. К. : КНТ, 2009. 224 c.

\section{References:}

1. Zakon Ukrainy «Pro zagal'noderzhavnu programu adaptaciï Zakonodavstva Ukraïni do zakonodavstva Evropejs'kogo Sojuzu» [The Law of Ukraine «On the national program of adaptation of the Legislation of Ukraine to the legislation of the European Union»]. (n.d.). zakon.rada.gov.ua. Retrieved from https://zakon.rada.gov.ua/laws/show/1629-15\#Text [in Ukrainian].

2. Bojko, Ju. Ju. (2018). Mizhnarodno-pravova koncepcija ohoroni prav pacienta [International legal concept of patient protection]. Pravova pozicija - Legal position, 2 (21),162-167 [in Ukrainian].

3. Gerc, A.A. (2016). Dogovirni zobov'jazannja u sferi nadannja medichnih poslug [Contractual obligations in the field of medical services]. Extended abstract of Doctor's thesis. Lviv: Lviv [in Ukrainian].

4. Senjuta, I. (2012). Prava ljudini u sferi ohoroni zdorovja [Human rights in the field of health care]. Kiev: Vidavnictvo TOV «Dizajn i poligrafija» [in Ukrainian].

5. Ukraïna kriz' prizmu Cvropejs'koï hartiï prav pacientiv: rezul'tati vikonannja $v$ Ukraïni drugogo etapu evropejs'kih doslidzhen' na vidpovidnist' standartam ES z prav pacientiv [Ukraine through the prism of the European Charter of Patients 'Rights: the results of Ukraine's 
implementation of the second stage of European research on compliance with EU standards on patients' rights]. Kiev: Vidavnictvo TOV «Dizajn i poligrafija» [in Ukrainian].

6. Galay, V.O, Grechanyuk, S.K., Senyuta, I.Y. (2009) Praktichne pravo: prava pacientiv (Interaktivnij kurs medichnogo prava) [Practical law: patients' rights (Interactive course of medical law)]. Kiev: Galaja. KNT [in Ukrainian]. 